\title{
Legalisasi Aborsi di Indonesia Perspektif Perbandingan Hukum Pidana: Antara Common Law System dan Civil Law System
}

\author{
Paulinus Soge \\ Fakultas Hukum Universitas Atma Jaya Yogyakarta \\ Jl. Mozes Gatotkaca No. 28 Yogyakarta \\ chrisp@mail.uajy.ac.id
}

\begin{abstract}
The purpose of this article is to discuss ius constituendum on abortion in Indonesia from criminal law perspective between Common Law System and Civil Law System. Ius constituendum on abortion in Indonesia is not directed to legalization of abortion as carried out both in The Netherlands and USA but tends to be harmonized with therapeutic abortion concept both in medical and psychiatric fields. Such a harmonization would result in the enlargement of exception in carrying out abortion not only limited on 'for saving mother's life based on medical indication' but also for other reasons such as 'pregnancy because of rape and incest', 'mother experiencing huge mental disorder' and 'the fetus experiencing huge physical destruction'.
\end{abstract}

Key words : abortion, criminal law, common law system, civil law system.

\begin{abstract}
Abstrak
Tulisan ini bertujuan untuk membahas tentang ius constituendum terhadap aborsi di Indonesia dari perspektif hukum kriminal, yaitu Sistem Hukum Umum dan Sistem Hukum Sipil. Ius constituendum terhadap aborsi di Indonesia tidak ditujukan untuk melegalkan aborsi seperti halnya di Belanda dan Amerika Serikat, akan tetapi lebih untuk menyelaraskan konsep aborsi terapetik dalam bidang medis dan kejiwaan. Dalam perkembangannya, keselarasan tersebut akan memperluas pengecualian dalam pelaksanaan aborsi, yaitu tidak hanya sebatas "menyelamatkan nyawa sang ibu berdasarkan indikasi medis", namun juga alasan-alasan lain, seperti "kehamilan karena perkosaan dan inses", "kelainan jiwa pada ibu", dan "janin yang mengalami kelainan fisik berat"
\end{abstract}

Kata kunci : aborsi, hukum pidana, sistem hukum umum, sistem hukum sipil 


\section{Pendahuluan}

Ketentuan hukum tentang aborsi terdapat di dalam Pasal 295 s.d. 298 KUHP Belanda 1881 yang dinyatakan tidak berlaku lagi setelah aborsi dilegalkan di Belanda dengan ditetapkannya Undang-Undang Pengguguran Kandungan 1 Mei 1981 Stb. 1981, 257 yang kemudian dirubah dengan Undang-undang tanggal 6 Nopember 1997, Stb. 1997, 510. Di dalam KUHP Indonesia yang masih berlaku sampai sekarang, aborsi diatur dalam Pasal 346 s.d. 349 KUHP yang termasuk dalam kejahatan terhadap nyawa, khususnya nyawa janin. Pasal-pasal tersebut merupakan turunan atau kopi dari Pasal 295 s.d. 298 KUHP Belanda 1881 yang dinyatakan tidak berlaku lagi sebagaimana telah diutarakan di atas.

Sebagai bahan perbandingan akan dibahas pula hukum aborsi AS yang termasuk dalam keluarga Common Law. Di AS, sampai dengan abad ke-19 hukum yang berlaku adalah common law Inggris yang membolehkan aborsi sebelum quickening (gerakan pertama bayi dalam kandungan setelah 16 s.d 18 minggu). ${ }^{1}$ Meskipun pada pertengahan dan akhir abad ke-19, perbedaan berdasarkan prinsip quickening hilang dari hukum perundang-undangan AS dan dibuat peraturan lebih keras yang melarang aborsi, namun pada tanggal 22 Januari 1973 MA AS menjatuhkan putusan yang melegalkan aborsi dalam perkara Roe v. Wade dan Doe v. Bolton. Putusan ini didasarkan pada amandemen ke-14 Konstitusi AS yang menjamin hak hidup, hak kebebasan dan memperoleh harta milik bagi semua orang, namun tidak dapat diperluas sampai pada perlindungan terhadap janin karena common law Inggris yang menjadi pola konstitusi AS tidak menentukan aborsi sebagai kejahatan.

Perubahan hukum yang berkaitan dengan aborsi baik di Belanda yang menganut Civil Law System dan di AS yang menganut Common Law System terjadi karena perubahan atau perkembangan masyarakat yang terjadi di kedua negara tersebut. Oleh karena itu diperlukan analisis dari perspektif perbandingan hukum, apakah perkembangan masyarakat Indonesia saat ini berkaitan dengan aborsi akan mengarah ke legalisasi aborsi seperti telah terjadi baik pada hukum aborsi Belanda maupun pada hukum aborsi AS.

\footnotetext{
${ }^{1}$ Bo Schambelan, J.D., Roe v. Wade; The Complete Text of The Official U.S. Supreme Court Decision, The most Controversial Ruling of Our time - Read It and Just It for Yourself, Philadelphia, Running Press, 1992, hlm.22.
} 


\section{Perubahan Hukum Aborsi Belanda karena Pengaruh Perkembangan Kehidupan Masyarakat}

Pasal 295 s.d. 298 KUHP Belanda 1881 yang memuat ketentuan hukum tentang aborsi mengalami pasang surut karena pada suatu saat mendapatkan pandangan yang lunak, pada saat lainnya diperketat, dan akhirnya dihapuskan samasekali dari KUHP Belanda 1881 dengan ditetapkannya undang-undang baru yang melegalkan aborsi.

Dikatakan demikian karena sampai akhir abad ke-19 aborsi masih merupakan fenomena yang tidak mendapatkan perhatian dalam kehidupan masyarakat Belanda, dan pada umumnya masih tetap ada pendapat-pendapat yang lunak terhadap aborsi. Salah satu pendapat yang lunak terhadap aborsi terlihat dalam tesis berkaitan dengan ketentuan hukum tentang aborsi yang ditulis oleh Van Tienhoven van den Bogaard ${ }^{2}$ berjudul 'Beschouwingen over artt. 295-298 van het Wetboek van Strafrecht' (Pandangan tentang Pasal 295-298 KUHP) tahun 1887.

Di dalam tesis tersebut van den Bogaard sangat meragukan larangan hukum terhadap aborsi. Bogaard khawatir jangan-jangan larangan ini akan menjadi tidak bijaksana dan akan meningkatkan angka pembunuhan anak atau bertambahnya jumlah anak haram, yang harus menjalani hidup mereka dengan nama cemar. Oleh karena itu Bogaard menyimpulkan bahwa pidana untuk pelaku aborsi terlalu berat, meskipun dari kacamata susila aborsi itu jelek. Berdasarkan kesimpulan tersebut Bogaard menyarankan agar pidana untuk pelaku aborsi diperingan saja, tidak boleh lebih dari satu bulan penjara.

Salah satu topik diskusi tentang aborsi dalam kehidupan masyarakat Belanda sampai tahun 1900 adalah keterkaitan antara aborsi kriminal dan aliran neo-Malthus. Oleh para penentangnya aliran ini diyakini mendorong aborsi kriminal sebagai upaya menekan laju pertumbuhan penduduk. Pendapat para penentang yang demikian itu mendapatkan posisi menguntungkan, ketika pada tahun 1911 dikeluarkan 'Undang-undang yang menentang pelanggaran susila' oleh Menteri E.R.H. Regout, ${ }^{3}$ seorang penganut Katolik Roma. Undang-undang ini memenuhi keinginan untuk memperketat pengaturan tentang aborsi dan memuat ketentuan untuk mengurangi penyebaran alat-alat kontrasepsi.

\footnotetext{
${ }^{2}$ Jan de Bruijn, Geschiedenis van de Abortus in Nederland; Een Analyse van Opvattingen en Discussies 1600-1979, Amsterdam, Van Gennep, 1979, hlm. 35.

${ }^{3}$ Ibid., hlm. 235
} 
Akan tetapi dengan adanya perubahan pandangan mengenai pengendalian penduduk sebelum Perang Dunia II, dan lebih-lebih setelah Perang Dunia II maka mulai ada pendekatan yang lebih positif terhadap kontrasepsi di dalam kehidupan masyarakat Belanda yang mencapai klimaksnya ketika pada tahun 1969, Parlemen dengan suara yang mendekati bulat, mengeluarkan pasal yang melarang kontrasepsi dari KUHP Belanda. Selain itu, pada tahun 1971 Komisi Aborsi mengeluarkan semacam kesepakatan yang dianggap sebagai keputusan bahwa ketentuan-ketentuan hukum pidana menyangkut aborsi pada saat itu dari semua segi kurang memuaskan, karena itu dapat dijadikan alasan untuk mengadakan perubahan. Berdasarkan perkembangan yang demikian itu, maka selama kurun waktu 1970 sampai 1979 tidak kurang dari tujuh rancangan undang-undang yang diajukan ke Parlemen untuk menggantikan peraturan perundang-undangan yang lama mengenai aborsi, dan pada tanggal 1 Mei 1981 ditetapkan Undang-undang Pengguguran Kandungan Stb. 1981, 257 yang kemudian dirubah dengan Undang-undang tanggal 6 Nopember 1997, Stb. 1997, 510 yang melegalkan aborsi. ${ }^{4}$ Dengan adanya undang-undang baru ini, maka Pasal 295 s.d. 298 dikeluarkan dari KUHP Belanda 1881 dan dinyatakan tidak berlaku lagi.

Bertolak dari uraian di atas, maka jelas terlihat perkembangan kehidupan masyarakat Belanda telah menyebabkan perubahan hukum tentang aborsi dari yang paling konservatif karena melarang aborsi tanpa pengecualian menjadi yang paling liberal karena membolehkan aborsi berdasarkan permintaan. Oleh karena itu berdasarkan hasil survei internasional $1995^{5}$ hukum aborsi Belanda dikelompokkan dalam hukum yang menganut model privasi (model of privacy) sejajar dengan AS, Jepang, Jerman, Perancis, Denmark dll. Perubahan itu terlihat pula dalam beberapa hasil studi lainnya. Hasil studi Rahman, et .al. ${ }^{6}$ menempatkan hukum aborsi Belanda pada kategori alasan No. 5 sejajar dengan 49 negara lainnya seperti AS, Perancis, Italia, Singapura, China, Rusia, Cuba dll. yang membolehkan aborsi tanpa pembatasan apapun.

Kebijakan aborsi jika dilihat dari yang paling liberal sampai dengan paling konservatif, hukum aborsi Belanda dapat ditempatkan dalam kategori A menurut

\footnotetext{
${ }^{4}$ Hans Akceld, Chronologisch Ovrzicht Wijzigingswetten, Denhag, Kluwer, 1997, hlm. 15.

${ }^{5}$ Anita L. Allen, "Legal and Regulatory Issues" dalam W. Th. Reich (ed), Encyclopedia of Bioethics, Rivised Edition, Volume 1, New York: Simon \& Schuster, 1995, hlm. 21.

${ }^{6}$ A. Rahman, et. All, "A Global Review of Laws on Induced Abortion, 1985-1997”' International Health Family Planning Perspectives, June (24), Number 2, 1998, hlm. 58.
} 
Indonesia Country Progress Report ${ }^{7}$ karena aborsi dibolehkan atas permintaan perempuan. Sedangkan dari segi kebijakan melegalkan aborsi berdasarkan pertimbangan kontekstual, menurut hasil survei $\mathrm{WHO},{ }^{8}$ hukum aborsi Belanda dapat ditempatkan dalam kategori alasan mengizinkan aborsi No. 7, sehingga Belanda termasuk dalam salah satu dari $27 \%$ negara-negara di dunia yang mengizinkan aborsi berdasarkan permintaan.

Bertolak dari perubahan-perubahan tersebut, maka hasil kajian Darwin ${ }^{9}$ menempatkan hukum aborsi Belanda pada posisi hukum sangat longgar sejajar dengan beberapa negara lain seperti AS, Perancis, Italia, Turki, Tunisia dan Singapura yang membolehkan aborsi atas permintaan ibu hamil karena berbagai alasan. Hal ini berarti perempuan mempunyai kebebasan penuh untuk melanjutkan atau menghentikan kehamilannya karena berbagai alasan.

Dari uraian di atas terlihat bahwa kenyataan di dalam kehidupan masyarakat Belanda berupa perubahan pandangan mengenai pengendalian penduduk sebelum Perang Dunia II, dan mencapai klimaksnya setelah Perang Dunia II telah membentuk opini publik bahwa peraturan hukum tentang aborsi Belanda dari segala segi kurang memuaskan, sehingga berdasarkan kebijakan legislatif pada 1 Mei 1981 ditetapkan Undang-undang Pengguguran Kandungan Stb. 1981, 257 yang kemudian dirubah dengan Undang-Undang 6 Nopember 1997, Stb. 1997, 510. Adanya undang-undang ini telah membuat perubahan besar dalam hukum aborsi Belanda, dari yang paling konservatif menjadi yang paling liberal.

\section{Perubahan Hukum Aborsi AS karena Pengaruh Perkembangan Kehidupan Masyarakat}

Sampai dengan pertengahan abad ke-19 hukum yang berlaku di AS adalah Common Law Inggris. Connecticut, negara bagian pertama yang memberlakukan perundangundangan aborsi, pada tahun 1821 mengadopsi bagian dari hukum aborsi Inggris yaitu Lord Ellenbrough's Act yang berkaitan dengan "quickening" pada wanita hamil. Undang-undang ini melarang aborsi setelah "quickening", dan menganggapnya

\footnotetext{
${ }^{7}$ Indonesia Country Progress Report, http://www.who.int/reproductive-health/mps/ indonesia_ cpuntry_report.html, 28 Maret 2002

${ }^{8}$ United Nations, Safe Abortion: Technical and Policy Guidance for Health Systems, Geneva World Health Organization, 2003, hlm. 14-15.

${ }^{9}$ Muhajir M. Darwin, Negara dan Perempuan; Reorientasi Kebijakan Publik, Yogyakarta, Media Wacana, 2005, hlm. 234.
} 
sebagai kejahatan utama (capital crime), tetapi menetapkan hukuman yang lebih ringan terhadap aborsi sebelum " quickening", dan dengan demikian mempertahankan perbedaan berdasarkan prinsip "quickening" di dalam common law.

Pada tahun 1828, New York memberlakukan perundang-undangan yang dalam dua hal dapat menjadi model perundang-undangan anti-aborsi awal. Pertama, undang-undang tersebut melarang perusakan janin baik sebelum maupun sesudah "quickening". Perusakan janin sebelum "quickening" dianggap sebagai pelanggaran, dan bila dilakukan sesudah "quickening" dianggap sebagai pembunuhan.

Kedua, undang-undang tersebut menyatukan konsep aborsi therapeutik dengan mengatur bahwa aborsi dimaafkan "apabila diperlukan untuk mempertahankan kehidupan ibu, atau dinasihatkan oleh dua dokter bersertifikat bahwa hal itu diperlukan untuk tujuan tersebut. Pada tahun 1840, ketika negara Bagian Texas menerima common law, hanya ada 8 negara bagian AS mempunyai undang-undang yang berkaitan dengan aborsi. Kebanyakan perundang-undangan yang awalnya mengatur secara keras aborsi setelah "quickening," tetapi lembut terhadap aborsi sebelum "quickening." Kebanyakan perundang-undangan menghukum percobaan melakukan aborsi sama dengan aborsi yang selesai, dan banyak pula yang memasukkan pengecualian untuk aborsi yang diperkenankan oleh satu atau lebih dokter yang diperlukan untuk menyelamatkan jiwa ibu.

Secara bertahap, pada pertengahan dan akhir abad ke-19, perbedaan berdasarkan prinsip "quickening" hilang dari hukum perundang-undangan, dan dibuat peraturan yang lebih keras terhadap aborsi. Pada akhir tahun 1950, sebagian besar yurisdiksi melarang aborsi, bagaimanapun caranya dan kapan pun dilakukan kecuali untuk menyelamatkan jiwa ibu; hanya Alabama dan District of Columbia, yang mengizinkan aborsi untuk mempertahankan kesehatan ibu. Ada pula beberapa negara bagian yang mengizinkan aborsi dilakukan secara tidak melawan hukum dan diserahkan kepada pengadilan untuk menginterpretasikan standar-standar yang berkaitan dengan pembenaran hukum.

Perubahan karakter hukum aborsi dari lembut beralih ke hukum yang keras terhadap aborsi sejak akhir tahun 1950 di AS dapat dihubungkan dengan fakta perkembangan kehidupan masyarakat AS. Pada akhir abad ke-19 di AS terjadi kemajuan pesat di bidang ilmu pengetahuan, sehingga timbul kesadaran bahwa perkembangan janin terjadi dalam suatu proses yang berkesinambungan dan bahwa kehidupan pada janin telah ada sebelum gerakan janin dapat dideteksi. Pesatnya 
kemajuan di bidang ilmu pengetahuan telah mematahkan prinsip "quickening" warisan common law Inggris.

Perkembangan yang terjadi di AS pada abad ke-19 itu dapat dikaitkan dengan perkembangan yang terjadi pada Gereja Katolik sebelumnya. Menurut Kusmaryanto, ${ }^{10}$ dalam Gereja Katolik waktu itu juga ada perbedaan antara sebelum dan sesudah janin berjiwa. Paus Gregorius XIV pada tahun 1591 menegaskan, bahwa hukuman eks-komunikasi (dikeluarkan dari Gereja) hanya diberlakukan bila seseorang melakukan aborsi pada saat janin sudah berjiwa, sedangkan kalau dilakukan sebelumnya, dia tidak dikeluarkan dari Gereja, meskipun pelakunya tetap berdosa.

Kusmaryanto ${ }^{11}$ selanjutnya menjelaskan pada tahun 1853 Ferdinand Kember menemukan bahwa pembuahan itu terjadi oleh karena pertemuan antara sel telur dan sel sperma. Dalam penemuan baru ini, disadari bahwa quickening bukanlah suatu titik yang penting dari seluruh proses perkembangan bayi. Penemuan baru itu tentu saja mendorong perubahan cara memandang embrio. Embrio mempunyai jiwa bukan beberapa hari sesudah pembuahan, tetapi sudah ada sejak terjadinya pembuahan. Gereja Katolik mendapat tekanan berat untuk mengubah pandangannya mengenai embrio, yang membedakan antara embrio yang belum berjiwa dan sudah berjiwa. Maka pada tahun 1869 Paus Pius IX menghilangkan pembedaan itu dan menegaskan bahwa barang siapa melakukan aborsi - kapan pun juga waktunya - akan mendapatkan hukuman eks-komunikasi.

Penemuan tentang perkembangan embrio yang berkembang secara kontinyu ini diperkuat lagi dengan penemuan struktur DNA (deoxyribonucleir acid) pada tahun 1953 oleh Franci s H. Crick dan James D. Watson. ${ }^{12}$ Di situ dijelaskan bahwa setelah selesainya proses pembuahan, semua faktor genetik manusia sudah ada di dalamnya dan hari-hari berikutnya hanya tinggal mengembangkan saja apa yang sudah ada di dalamnya. Jadi tidak ada pentahapan yang berarti, sehingga bisa dikatakan dengan persis bahwa ada masa belum berjiwa dan ada masa sudah berjiwa. Tentu saja penemuan struktur DNA ini merubah arah ilmu genetika dan menjadikan studi tentang gen sebagai ilmu yang penting dan mendasar untuk biologi modern hingga sekarang.

\footnotetext{
${ }^{10}$ CB. Kusmaryanto, SCJ, Kontroversi Aborsi, Jakarta, PT Grasindo, 2002, hlm. 27-28.

${ }^{11}$ Loc. Cit., hlm. 28.

${ }^{12}$ Ibid., hlm. 29.
} 
Didorong oleh perkembangan pengetahuan medis yang baru tersebut, maka menurut Rosenfield dan Iden, ${ }^{13}$ American Medical Association (AMA) mulai secara terbuka menentang aborsi dan menganggapnya sebagai praktik yang amoral. AMA mempunyai pengaruh yang sangat besar dalam pembentukan undang-undang aborsi yang lebih keras pada waktu itu.

Oleh karena itu pada tahun 1967 Komisi Reproduksi Manusia (Committee on Human Reproduction) AMA mendesak agar dibuat kebijakan menentang aborsi yang disengaja, kecuali apabila ada dokumen medis sebagai bukti adanya ancaman terhadap kesehatan atau nyawa ibu, atau bahwa anak yang akan lahir mengalami cacat fisik atau mental yang akan membuatnya tidak mampu hidup sebagai manusia normal, atau bahwa kehamilan itu disebabkan oleh perkosaan atau incest yang akan mengancam kesehatan mental atau fisik pasien, dimana dua dokter lainnya yang dipilih karena kewenangan profesinya telah memeriksa pasien dan memberikan pendapat tertulis, dan bahwa prosedur aborsi dilaksanakan di rumah sakit yang terakreditasi.

Kerasnya undang-undang aborsi di AS saat itu tidak hanya dirasakan oleh Roe dan Doe, tetapi juga oleh para perempuan AS lainnya serta para dokter yang hidup pada masa Roe dan Doe. Para perempuan AS pada masa Roe dan Doe yang mengalami kehamilan yang tidak diinginkan (KTD) tidak dapat melakukan aborsi aman dan legal karena KTD tersebut tidak mengancam jiwa mereka. Mereka menyadari bahwa hak privasi mereka untuk melanjutkan atau menghentikan kehamilannya sebenarnya dilindungi oleh amandemen ke-1, ke-4, ke-5, ke-9 dan ke-14 Konstitusi AS, meskipun kebanyakan negara bagian memberlakukan undang-undang yang pada prinsipnya melarang aborsi.

Para dokter yang hidup pada masa Roe dan Doe pun mengalami hal yang serupa. Meskipun mereka bersertifikat dan berkompeten untuk melakukan aborsi berdasarkan kondisi yang aman dan klinis di rumah sakit yang terakreditasi, mereka sering menghadapi resiko ditahan dan dituntut karena melanggar undang-undang aborsi. Mereka menggambarkan kondisi para pasien yang datang kepada mereka meminta dilakukan aborsi, dan sebagai dokter, mereka menyatakan bahwa dalam banyak kasus mereka tidak mampu menentukan apakah aborsi yang mereka lakukan itu termasuk dalam pengecualian atau menyimpang dari undang-undang aborsi

${ }^{13}$ A Rosenfield dan S. Iden, “Abortion; Medical Perspectives”, dalam W. Th. Reich (ed), Encyclopedia of Bioethics, Rivised Edition, Volume 1, New York: Simon \& Schuster, 1995, hlm. 4. 
negara bagian. Mereka akhirnya menyadari bahwa undang-undang aborsi negara bagian kabur dan tidak pasti, serta bertentangan dengan amandemen ke-14 Konstitusi AS. Mereka juga menyadari bahwa undang-undang aborsi negara bagian bertentangan dengan hak privasi mereka sendiri sebagai dokter dan juga melanggar hak privasi para pasien mereka dalam hubungan antara dokter-pasien serta melanggar hak mereka sendiri untuk mempraktekkan obat, hak yang menurut mereka dijamin oleh Amandemen ke-1, ke-4, ke-5, ke-9 dan ke-14 Konstitusi AS.

Kenyataan kehidupan masyarakat AS yang demikian itu telah mondorong adanya proses pengadilan perkara aborsi yang sangat terkenal, yaitu perkara Roe v. Wade dan Doe v. Bolton. Dalam kedua perkara ini Pengadilan Wilayah Texas menjatuhkan putusan pada tahun 1970 yang menetapkan bahwa wanita mempunyai hak untuk memilih apakah melahirkan atau tidak yang dilindungi oleh Amandemen ke-14 Konstitusi AS, dan bahwa Undang-undang Aborsi Texas dan Georgia dinyatakan tidak berlaku karena dari segi konstitusi tidak pasti dan mengandung pelanggaran berat terhadap hak penggugat yang diatur dalam Amandemen ke-14. Sejak itu aborsi telah menjadi isu kontroversial di AS dan para aktivis mulai menentang validitas undang-undang aborsi, dan perjuangan mereka membawa hasil ketika MA AS pada tanggal 22 Januari 1973 menjatuhkan putusan dalam perkara Roe v. Wade dan Doe v. Bolton yang menetapkan bahwa hukum aborsi Texas dan Georgia inkonstitusional dengan demikian aborsi dilegalkan.

Di dalam kepustakaan hukum pidana putusan MA AS tahun 1973 tersebut merupakan putusan penting dan bersejarah (landmark decision) karena memberikan kerangka waktu tiga bulan (a trimester framework), sehingga aborsi dapat dibedakan dalam tiga kategori: first trimester abortion (aborsi trimester pertama), second trimester induction (induksi trimester kedua), dan third trimester induction (induksi trimester ketiga).

Undang-undang aborsi AS berlandaskan pada putusan MA AS tersebut memberikan batas waktu yang jelas yaitu pada saat janin mampu hidup di luar rahim (viable, sekitar 24 minggu), sehingga sebelum saat tersebut yaitu pada trimester pertama perempuan mempunyai hak untuk memilih menghentikan kehamilannya dan berhak membuat keputusan pribadi dengan dokternya tanpa campur tangan negara (negara bagian). Sedangkan setelah saat tersebut yaitu pada trimester kedua dan ketiga, negara (negara bagian) perlu campur tangan untuk memberikan perlindungan terhadap kehidupan janin karena terdapat kemungkinan yang realistik untuk mempertahankan dan mengasuh kehidupan di luar rahim. 
Berkaitan dengan hal tersebut maka pada trimester kedua hanya dalam keadaan terpaksa negara (negara bagian) dapat mengatur prosedur induksi yang layak untuk melindungi dan menjaga kesehatan perempuan. Sedangkan pada trimester ketiga induksi samasekali dilarang karena negara (negara bagian) berkewajiban melindungi kehidupan yang potensial, kecuali memang diperlukan untuk menyelamatkan jiwa ibu atau kesehatan ibu.

Putusan MA AS tersebut terasa sangat kontroversial karena sebelum MA AS menjatuhkan putusan melegalkan aborsi tanggal 22 Januari 1973 dalam perkara Roe v. Wade dan Doe v. Bolton, sebenarnya aborsi yang dibolehkan di AS hanyalah aborsi therapeutik untuk menyelamatkan jiwa ibu atau untuk kesehatan ibu. Maka jelas kedua putusan tersebut dalam kepustakaan hukum pidana tetap dikenang sebagai dua putusan penting dan bersejarah (landmark decisions) karena membawa perubahan besar dalam perkembangan hukum tentang aborsi di AS, dari hukum aborsi konservatif yang hanya membolehkan aborsi berdasarkan pertimbangan medis menjadi hukum aborsi liberal yang membolehkan aborsi berdasarkan permintaan karena berbagai alasan.

Menurut $\mathrm{O}^{\prime}$ Conner, ${ }^{14}$ sejak awal perlu ditegaskan kembali dasar putusan Roe v. Wade dan Doe v. Bolton, yang memberikan teori tiga kerangka waktu tersebut, yaitu:

1. Putusan itu merupakan pengakuan terhadap hak privasi perempuan untuk memilih aborsi sebelum janin mampu hidup di luar rahim dan dapat melakukannya tanpa campur tangan negara. Sebelum janin mampu hidup di luar rahim kepentingan negara tidak cukup kuat untuk mendukung larangan aborsi atau hambatan terhadap hak privasi perempuan untuk memilih prosedur aborsi.

2. Putusan tersebut merupakan konfirmasi terhadap kekuasaan negara untuk melarang induksi setelah janin mampu hidup di luar rahim, apabila hukum mengatur tentang pengecualian terhadap kehamilan yang membahayakan kehidupan atau kesehatan perempuan.

3. Prinsip bahwa negara mempunyai kepentingan yang sah untuk melindungi kehidupan janin yang dapat menjadi seorang anak. Prinsip-prinsip ini tidak saling bertentangan dan setiap prinsip menjadi pegangan bangsa AS.

Oleh karena itu O'Conner ${ }^{15}$ menyimpulkan bahwa batas waktu harus ditarik pada saat janin mampu hidup di luar rahim, sehingga sebelum saat tersebut, perempuan mempunyai hak privasi untuk memilih menghentikan kehamilannya. Kita berpegang pada prinsip ini karena dua alasan:

${ }^{14}$ S. D. O’Conner, “Majority Opinion”, dalam M. Ethan Katsh (ed), Taking Sides: Clashing Views on Controversial Legal Issues, Guilford, Dushkin Publisihing Group, 1995, hlm. 113.

${ }^{15}$ Ibid., hlm. 119-120. 
1. Setiap tindakan pengadilan untuk menarik garis batas dapat merupakan suatu perbuatan yang sewenang-wenang, tetapi dalam keputusan Roe dan Doe hal tersebut dielaborasi dengan sangat teliti.

2. Konsep kemampuan hidup di luar rahim, sebagaimana dapat diketahui dalam putusan Roe dan Doe, adalah saat dimana terdapat kemungkinan yang realistik untuk mempertahankan dan mengasuh kehidupan di luar rahim, sehingga keberadaan yang bebas dari kehidupan anak dalam kandungan mendapatkan perlindungan dari negara yang sekarang melebihi hak perempuan.

Menurut Adjie, ${ }^{16}$ putusan MA dalam putusan Roe v. Wade dan Doe v. Bolton, mengeluarkan suatu ruling, bahwa keputusan untuk melakukan aborsi pada trimester pertama adalah hak fundamental mengenai kebebasan privasi dari wanita hamil yang bersangkutan dan karenanya perlu dilindungi terhadap pelanggaran yang tak wajar dari negara-negara (bagian). Hanya dalam trimester kedua dan ketiga pengaturan hukum tentang induksi dapat diadakan.

Lebih lanjut Adjie, ${ }^{17}$ menegaskan bahwa putusan MA AS tentang aborsi tersebut dihubungkan dengan "right of privacy", yang dikatakan bahwa hak tersebut adalah cukup luas untuk meliputi putusan dari wanita yang bersangkutan untuk mengakhiri kehamilannya atau tidak ("is broad enough to encompass a woman's decision whether or not to terminate her pregnancy"). Bagaimanapun juga, putusan tersebut menunjukkan dengan jelas, bahwa wanita ataupun dokter yang bersangkutan dapat mengambil ketentuan sendiri tanpa adanya campur tangan pemerintah dalam trimester pertama.

Dikatakan bersejarah dan membawa perubahan besar, karena kedua putusan tersebut tidak hanya menjungkirbalikkan hukum aborsi Texas dan Georgia, tetapi juga menyebabkan hampir semua negara bagian harus merevisi hukum aborsinya. Maka dapat dipahami bahwa hukum aborsi AS berdasarkan putusan MA AS tanun 1973 dalam perkara Roe v. Wade dan Doe v. Bolton menurut hasil survei internasional $1995^{18}$ dikelompokkan dalam hukum yang menganut model privasi (model of privacy) karena pada trimester pertama perempuan mempunyai hak privasi untuk menentukan apakah melanjutkan atau menghentikan kehamilannya bersama dokternya tanpa campur tangan negara (negara bagian).

Perubahan itu terlihat pula dalam beberapa hasil studi lainnya. Hasil studi Rahman, et $. a l .{ }^{19}$ menempatkan hukum aborsi AS berdasarkan putusan MA AS tahun 1973 pada kategori alasan No. 5 sejajar dengan 49 negara lainnya seperti Perancis,

\footnotetext{
${ }^{16}$ O. S. H. Adji, Hukum-Hakim Pidana, Cet. Ke-2, Jakarta, Erlangga, 1984, hlm. 206.

${ }^{17}$ Ibid., hlm. 207.

${ }^{18}$ Anita L. Allen, Op. Cit., hlm. 21.

${ }^{19}$ A. Rahman, et. All, Op. Cit., hlm. 15.
} 
Belanda, Italia, Singapura, China, Rusia, Cuba dll. yang membolehkan aborsi tanpa pembatasan apapun. Dari segi kebijakan aborsi dari yang paling liberal s.d. paling konservatif, hukum aborsi AS berdasarkan putusan MA AS tahun 1973 dapat ditempatkan dalam kategori A menurut Indonesia Country Progress Report $2002^{20}$ karena aborsi dibolehkan atas permintaan perempuan. Sedangkan dari segi kebijakan melegalkan aborsi berdasarkan pertimbangan kontekstual hasil survey $\mathrm{WHO}^{21}$ hukum aborsi AS berdasarkan putusan MA AS tahun 1973 dapat ditempatkan dalam kategori alasan mengizinkan aborsi No. 7, sehingga AS termasuk dalam salah satu negara dari 27\% negara-negara di dunia yang mengizinkan aborsi berdasarkan permintaan.

Dengan adanya perubahan tersebut, maka hasil kajian Darwin ${ }^{22}$ menempatkan hukum aborsi AS berdasarkan putusan MA AS tahun 1973 pada posisi hukum sangat longgar sejajar dengan beberapa negara lain seperti Perancis, Italia, Belanda, Tunisia, Turki, dan Singapura yang membolehkan aborsi atas permintaan ibu hamil karena berbgai alasan. Hal ini berarti perempuan mempunyai kebebasan penuh untuk melanjutkan atau menghentikan kehamilannya pada trimester pertama karena berbagai alasan.

Dari uraian di atas dapat dikatakan bahwa kenyataan di dalam kehidupan masyarakat AS berupa kerasnya hukum aborsi AS sejak tahun 1950 telah menimbulkan keresahan di kalangan perempuan AS yang mengalami KTD. Kenyataan ini telah mendorong dilakukannya proses perkara Roe v. Wade and Doe v. Bolton, maka berdasarkan kebijakan yudikatif berupa putusan MA AS pada tanggal 22 Januari 1973 yang melegalkan aborsi pada trimester pertama, telah terjadi perubahan hukum tentang aborsi di AS dari yang paling konservatif menjadi yang paling liberal.

\section{Pengaturan hukum tentang aborsi yang dimungkinkan/seharusnya berlaku di Indonesia}

Dari uraian di atas dapat dikatakan bahwa baik hukum aborsi AS yang menganut common law system maupun hukum aborsi Belanda yang menganut civil law system

\footnotetext{
${ }^{20}$ Indonesia Country Progress Report, Op.Cit.

${ }^{21}$ United Nations, Op.Cit., hlm.14-15.

${ }^{22}$ Muhajir M. Darwin, Op. Cit., hlm. 234.
} 
mengalami perkembangan yang serupa, yaitu telah berubah dari hukum aborsi yang bersifat restriktif menjadi liberal. Dikatakan demikian, karena pada mulanya baik hukum aborsi AS maupun hukum aborsi Belanda menganut model larangan (model of prohibition) dan kemudian berubah menjadi sangat liberal dan menganut model privasi (model of privacy).

Di Indonesia, sejak diberlakukannya KUHP yang diadopsi dari KUHP Belanda 1881 berdasarkan UU No. 1 Tahun 1946, ketentuan hukum tentang aborsi menganut model larangan (model of prohibition) karena aborsi dilarang tanpa pengecualian sebagaimana diatur di dalam Pasal 346 s.d. 349 KUHP yang merupakan kopi atau turunan dari Pasal 295 s.d. 298 KUHP Belanda 1881. Kemudian model larangan yang dianut di dalam KUHP ini disempurnakan dengan adanya pengecualian setelah dikeluarkannya UU No. 23 Tahun 1992 tentang Kesehatan (UUK), meskipun hanya terbatas pada alasan medis untuk menyelamatkan jiwa ibu dalam keadaan darurat. Oleh karena itu hukum pidana yang berkaitan dengan aborsi atau ius constitutum tentang aborsi di Indonesia tergolong hukum yang paling konservatif dan keras terhadap aborsi karena melarang aborsi kecuali untuk menyelamatkan jiwa ibu.

Namun setelah International Conference on Population and Development (ICPD) Kairo 1994 dan Fourth World Conference on Women (FWCW) Beijing 1995, dirancang RUU Amandemen UUK yang mengacu pada kesepakatan ICPD Kairo 1994 tentang hak reproduksi perempuan dan secara implisit melegalkan aborsi karena membolehkan aborsi aman, bermutu dan bertanggung jawab untuk menghindarkan perempuan yang mengalami KTD dari praktek aborsi tidak aman yang sering merenggut jiwa perempuan.

Pengaturan hukum tentang aborsi di dalam RUU Amandemen UUK telah memicu opini publik yang pro dan kontra, khususnya antara para tokoh Pro-Choice dan Pro-Life dan telah menyeret kedua kubu untuk melakukan debat publik baik yang ditayangkan di TV maupun disampaikan dalam forum seminar nasional. Hasil analisis tentang debat publik tersebut memperlihatkan perbedaan yang tajam antara kedua kubu. Kubu Pro-Life menolak RUU Amandemen UUK dengan alasan, apabila RUU tersebut disahkan, maka akan terjadi legalisasi aborsi di Indonesia. Mereka cenderung mempertahankan UUK dengan catatan perlu dilengkapi dengan PP sebagaimana diamanatkan Pasal 15 ayat (3). Sebaliknya kubu Pro-Choice mendesak agar RUU tersebut segera disahkan untuk menghindarkan perempuan yang mengalami KTD dari praktek aborsi tidak aman (unsafe abortion) yang seringkali merenggut nyawa perempuan. 
Dari uraian di atas dapat dikatakan bahwa dalam menghadapi perkembangan kehidupan masyarakat Indonesia sekarang ini ada dua pilihan ius constituendum tentang aborsi yang dimungkinkan. Pertama, ketentuan yang hanya membolehkan aborsi berdasarkan indikasi medis untuk menyelamatkan jiwa ibu dalam keadaan darurat sebagaimana diatur di dalam UUK tetap dipertahankan dengan kewajiban untuk melengkapinya dengan PP sebagaimana diamanatkan Pasal 15 ayat (3) UUK. Kedua, mengesahkan RUU Amandemen UUK yang memuat ketentuan yang pada dasarnya melegalkan aborsi aman berdasarkan permintaan perempuan yang mengalami KTD karena mengacu pada kesepakatan ICPD Kairo 1994 tentang hak reproduksi.

Berdasarkan analisis taraf sinkronisasi vertikal dan horizontal, dapat diketahui bahwa RUU Amandemen UUK tidak sikron secara vertikal dan horisontal dengan peraturan perundang-undangan lainnya dalam hukum positif Indonesia, karena cenderung melegalkan aborsi. Maka dapat dikatakan bahwa secara yuridis RUU Amandemen UUK mempunyai cacat hukum. Akibatnya apabila RUU ini disahkan menjadi UU, resiko yang dihadapi ialah bahwa UU yang baru tersebut akan dinyatakan batal demi hukum.

Analisis tentang hukum aborsi yang dimungkinkan/seharusnya berlaku di Indonesia perlu dikaitkan dengan pengertian aborsi baik dari segi medis maupun psikiatri. Dari segi medis menurut Sofoewan, ${ }^{23}$ aborsi atas indikasi medis disebut juga aborsi terapeutik, yaitu aborsi yang dilakukan sebelum janin mampu hidup demi untuk kesehatan ibu: 1) untuk menyelamatkan jiwa ibu, 2) melindungi kesehatan ibu, 3) janin cacat berat sehingga tidak mampu hidup, 4) kehamilan yang tidak mampu hidup, 5) pengurangan janin pada kehamilan ganda, 6) kehamilan sangat merugikan kesehatan fisik dan mental ibu, 7) bayi yang akan dilahirkan akan menderita kelainan fisik dan mental, atau 8) kehamilan sebagai akibat dari perkosaan dan incest.

Sedangkan dari segi psikiatri menurut Soewadi, ${ }^{24}$ aborsi berdasarkan indikasi medis atau aborsi terapeutik dapat dilakukan jika: 1) kehamilan yang mengakibatkan resiko bagi kehidupan perempuan hamil, baik dari segi kesehatan fisik maupun

${ }^{23}$ Sulchan Sofoewan, "Kapan Dimulainya Kebidupan, Tahap-Tahap Kehidupan Janin Dalam Kandungan Dan Aborsi Legal Persepktof Medis", disampaikan dalam Seminar Nasional "Aborsi Legal di Indonesia Perspektif Hukum Pidana, Medis, Psikiatri \& Sosial Serta Opini Publik Yang Berkembang dalam Masyarakat”, Yogyakarta, Bagian Hukum Pidana FH UAJY, 24 Februari 2005, hlm. 4.

${ }^{24}$ H. Soewadi, "Aborsi Legal di Indonesia Perspektif Psikiatr", disampaikan dalam Seminar Nasional "Aborsi Legal di Indonesia Perspektif Hukum Pidana, Medis, Psikiatri \& Sosial Serta Opini Publik Yang Berkembang dalam Masyarakat”, Yogyakarta, B agian Hukum Pidana FH UAJY, 24 Februari 2005, hlm. 5. 
mental, 2) adanya resiko keutuhan fisik bayi yang akan dilahirkan (pertimbangan eugenik), 3) dan perkosaan dan incest (pertimbangan yuridis).

Apabila pengaturan hukum tentang aborsi yang dimungkinkan/seharusnya berlaku di Indonesia diharmonisasikan dengan konsep aborsi terapeutik sebagaimana diutarakan di atas, maka aborsi legal di Indonesia tidak hanya terbatas pada "aborsi berdasarkan indikasi medis untuk menyelamatkan jiwa ibu dalam keadaan darurat", tetapi lebih luas lagi mencakup beberapa alasan aborsi terapeutik baik dari segi medis maupun psikiatri yaitu: kehamilan akibat perkosaan dan incest, perempuan hamil mengalami gangguan jiwa berat, dan janin mengalami cacat bawaan berat.

Harmonisasi pengaturan hukum tentang aborsi ini membawa konsekuensi lebih lanjut berupa dekriminalisasi dan depenalisasi dalam pengaturan hukum pidana berkaitan dengan aborsi yang akan direalisasikan dalam kebijakan formulasi, aplikasi dan eksekusi untuk memenuhi asas lex certa dalam hukum pidana. Hal ini diperlukan karena ketiga alasan aborsi aman, yaitu kehamilan akibat perkosaan dan incest, perempuan hamil yang mengalami gangguan jiwa berat, dan janin yang mengalami cacat bawaan berat, di dalam ius constitutum merupakan perbuatan pidana karena itu dilarang dan diancam dengan pidana, namun dalam ius constituendum meskipun perbuatan-perbuatan tersebut tetap bersifat melawan hukum, perempuan hamil dan tenaga medis yang membantu melakukan aborsi tidak dipidana karena tidak mempunyai kesalahan berdasarkan pengecualian berupa alasan pemaaf sebagai alasan penghapusan pidana yang bersumber dari Pasal 48 KUHP tentang daya paksa (overmacht) dan kondisi darurat (noodtoestand).

Penerapan Pasal 48 KUHP terhadap ketiga alasan aborsi tersebut dilandasi oleh teori perlindungan hukum yang seimbang yang bersumber pada Pancasila, yang dapat diukur dengan ide yaitu justice yang memuat konsep iustitia distributive. ${ }^{25}$ Konsep iustitia distributive tersebut dengan jelas menggambarkan dua hal, yaitu kewajiban pemerintah untuk membagikan kesejahteraan kepada warga negaranya dan hak warganegara untuk memperoleh kesejahteraan dari pemerintah. Konsep iustitia distributiva jelas terlihat di dalam pernyataan pada alinea IV Pembukaan UUD 1945 yang memuat salah satu tujuan didirikannya Negara Republik Indonesia dan menjadi landasan politik hukum Indonesia yaitu "melindungi segenap bangsa Indonesia dan seluruh tumpah darah Indonesia." Begitu umumnya perlindungan

${ }^{25}$ P.J. Suwarno, Pancasila Budaya Bangsa Indonesia; Penelitian Pancasila dengan Pendekatan Historis, Filosofis \& SosioYuridis Kenegaraan, Yogyakarta, Penerbit Kanisius, 1993, hlm. 86. 
yang diberikan oleh negara yaitu kepada segenap bangsa Indonesia dan tumpah darah Indonesia, maka dapat dikatakan bahwa perlindungan itu tidak hanya diberikan kepada orang pada umumnya, tetapi juga kepada anak dalam kandungan. Dengan demikian anak dalam kandungan berhak untuk mendapatkan perlindungan dari negara.

Apabila dibandingkan dengan Konstitusi AS, jelas terlihat adanya perbedaan yang mendasar dalam hal perlindungan terhadap anak dalam kandungan. Kenyataan bahwa common law Inggris yang menjadi pola Konstitusi AS tidak menentukan aborsi sebagai kejahatan. Oleh karena itu perlindungan yang diberikan oleh amandemen ke-14 Konstitusi AS kepada "semua orang" tidak diperluas sampai pada perlindungan terhadap anak dalam kandungan pada trimester pertama. Hal ini dikukuhkan dalam putusan MA AS pada tahun 1973 dalam perkara Roe v. Wade dan Doe v. Bolton yang sangat terkenal itu.

Demikian pula jika dibandingkan dengan Undang-undang Pengguguran Kandungan Belanda tanggal 1 Mei Stb. 1981, 257 Stb. 1981, 257 yang kemudian dirubah dengan Undang-undang tanggal 6 Nopember 1997, Stb. 1997, 510., perlu ditegaskan bahwa aborsi yang dibebaskan di Belanda adalah aborsi aman (safe abortion) sampai dengan janin berusia 12 minggu. Di Indonesia tidak dikenal batas waktu yang demikian itu, sehingga negara mempunyai kewajiban untuk memberikan perlindungan kepada anak dalam kandungan mulai dari saat konsepsi sampai sebelum dilahirkan.

Perlindungan kepada anak dalam kandungan lebih jelas lagi dengan adanya pernyataan di dalam alinea IV Pembukaan UUD 1945 bahwa Negara Indonesia berdasarkan Pancasila. Sila pertama, Ketuhanan Yang Maha Esa, dan sila kedua, Kemanusiaan yang adil dan beradab, mempertegas adanya perlindungan konstitusi terhadap anak dalam kandungan yang memperoleh kehidupan dari Tuhan sang Pencipta dan karena itu manusia sesuai kodratnya berkewajiban melindungi, mengasuh, membesarkan dan menjaga kelangsungan hidupnya.

\section{Penutup}

Berdasarkan analisis sebagaimana dikemukakan di atas maka dapat diambil kesim-pulan bahwa "dari perspektif perbandingan hukum pidana antara common law system dan civil law system, ius constituendum tentang aborsi di Indonesia tidak 
mengarah ke legalisasi aborsi seperti terjadi di Belanda dan AS, tetapi cenderung diharmonisasikan dengan konsep aborsi terapeutik baik dari segi medis maupun psikiatri". Hal ini berarti aborsi dibolehkan tidak hanya terbatas pada alasan 'aborsi berdasarkan indikasi medis untuk menyelamatkan jiwa ibu dalam keadaan darurat', tetapi lebih luas lagi mencakup beberapa alasan lain yaitu: 'kehamilan akibat perkosaan dan incest', 'perempuan hamil mengidai gangguan jiwa berat', dan 'janin mengalami cacat bawaan berat'. Maka yang perlu dilakukan adalah merevisi UUK sesuai dengan amanat Pasal 15 ayat (3) dan bukan dengan mengesahkan RUU Amandemen UUK.

\section{Daftar Pustaka}

Adji, O. S. H., Hukum-Hakim Pidana, Cet. Ke-2, Jakarta, Erlangga 1984.

Akceld, Hans, Chronologisch Ovrzicht Wijzigingswetten, Denhag, Kluwer, 1997.

Allen, Anita L., "Legal and Regulatory Issues” dalam W. Th. Reich (ed), Encyclopedia of Bioethics, Revised Edition, Volume 1, New York, Simon \& Schuster, 1995.

Barda Nawawi Arief, , Perbandingan Hukum Pidana, Jakarta, CV. Rajawali, 1990.

Bellefroid, J.P.H., Inleiding Tot De Rechtswetenschap In Nederland, Nijmegen, Dekker \& Van de Vegt N.V., 1950.

Bruijn, Jan de., Geschiedenis van de Abortus in Nederland; Een Analyse van Opvattingen en Discussies 1600-1979, Amsterdam, Van Gennep, 1979.

Crabtree, A. P., You and The Law, New York, Holt, Rinehart and Winston Inc, 1964.

Indonesia Country Progress Report, http://www.who.int/reproductive-health/ $\mathrm{mps}$ / indonesia_cpuntry_report.html, 28 Maret2002.

Kusmaryanto, CB. SCJ. Kontroversi Aborsi, Jakarta, PT Grasindo, 2002.

Merryman, John Henry, The Civil Law Tradition; An Introduction To The Legal System of Western Europe and Latin America, Second edition, Standford, Standford university Press. 1985.

Muhajir M. Darwin, Negara dan Perempuan; Reorientasi Kebijakan Publik, Yogyakarta, Media Wacana, 2005.

O'Conner, S. D., “Majority Opinion”, dalam M. Ethan Katsh (ed), Taking Sides: Clashing Views on Controversial Legal Issues, Guilford, Dushkin Publisihing Group, 1995.

P.J.Suwarno. , Pancasila Budaya Bangsa Indonesia; Penelitian Pancasila dengan Pendekatan Historis, Filosofis \& Sosio - Yuridis Kenegaraan, Yogyakarta, Kanisius, 1993.

Rahman, A., Katzive L., dan Henshaw, S.K., "A Global Review of Laws on Induced Abortion, 1985-1997" International Health Family Planning Perspectives, June (24), 1998, Pp. 56-71. 
Rosenfield, A. dan Iden, S., “Abortion; Medical Perspectives”, dalam W. Th. Reich (ed), Encyclopedia of Bioethics, Rivised Edition, Volume 1, New York, Simon \& Schuster, 1995.

Schambelan, Bo, J.D. Roe v. Wade, The Complete Text of The Official U.S. Supreme Court Decision, The most Controversial Ruling of Our time - Read It and Just It for Yourself, Philadelphia, Running Press, 1992.

Soewadi, H., "Aborsi Legal di Indonesia Perspektif Psikiatri," Makalah disampaikan pada Seminar Nasional "Aborsi Legal Di Indonesia Perspektif Hukum Pidana, Medis, Psikiatri E Sosial Serta Opini Publik Yang Berkembang Dalam Masyarakat," Yogyakarta, Bagian Hukum Pidana, FH-UAJY, 24 Februari2005.

Sulchan Sofoewan, M., "Kapan Dimulainya Kehidupan, Tahap-Tahap Kehidupan Janin Dalam Kandungan Dan Aborsi Legal Perspektif Medis," Makalah disampaikan pada Seminar Nasional "Aborsi Legal Di Indonesia Perspektif Hukum Pidana, Medis, Psikiatri \& Sosial Serta Opini Publik Yang Berkembang Dalam Masyarakat," Yogyakarta, Bagian Hukum Pidana, FH-UAJY, 24 Februari 2005.

United Nations, Safe Abortion: Technical and Policy Guidance for Health Systems, Geneva, World Health Organization 2003.

Zweigert, Konrad dan Hein Kotz, 1998. Introduction To Comparative Law, Third Revised Edition, Translated from the German by Tony Weir, Fellow of Trinity College, Cambridge, Oxford: Clarendon Press. 